\author{
Anna Młynarczuk-Sokołowska \\ Uniwersytet w Białymstoku \\ E-MAIL: annamlynarczuk@o2.pl \\ Katarzyna Szostak-Król \\ Szkoła Podstawowa nr 26 w Białymstoku \\ E-MAIL: kaszost@02.pl
}

\title{
Przez trudy do gwiazd. Inkluzja i różnorodność w edukacji
}

Per angusta in augusta

(Przez trudy do wielkich rzeczy) ${ }^{1}$

\section{STRESZCZENIE}

Głównym celem artykułu jest prezentacja projektu edukacyjnego „Przez trudy do gwiazd” w kontekście założeń edukacji inkluzywnej. Autorki artykułu rozpoczynają od przedstawiania zagadnienia różnorodności i inkluzji w edukacji oraz założeń edukacji inkluzyjnej, po czym prezentują istotę projektu „Przez trudy do gwiazd”. Ostatnią część tekstu wzbogacają wypowiedzi uczestników projektu na temat ich doświadczeń związanych z uczestnictwem w działaniu.

SŁOWA KLUCzowE: różnorodność, edukacja inkluzyjna, kompetencje kluczowe, kooperatywne uczenie się.

\section{Wprowadzenie}

Przestrzeń edukacji jest przestrzenią wieloaspektowych zróżnicowań. Wystarczy obserwacja szkolnego czy przedszkolnego korytarza, aby dostrzec szereg różnic pomiędzy dziećmi. Ich podłożem są cechy biologiczne, charakterologiczne, wiążące się ze statusem ekonomicznym, czy też te wynikające z przynależności kulturowej czy religijnej². Odmienność może wzbudzać emocje zarówno pozytywne, jak i negatywne, stanowić kryterium podziałów, obcości, generować trudności związane z partycypacją w edukacji, a nawet

Sentencja łacińska.

2 Szerzej na ten temat zob. J. Nikitorowicz, Kreowanie tożsamości dziecka. Wyzwania edukacji międzykulturowej, GWP, Gdańsk 2005, s. 105 i nast.; P. P. Grzybowski, Edukacja międzykulturowa - przewodnik. Pojęcia - literatura - adresy, Impuls, Kraków 2008, s. 10. 
stanowić czynnik wykluczenia z edukacji i życia społecznego³. We współczesnej, coraz bardziej zróżnicowanej rzeczywistości, znaczenia nabiera podejmowanie działań edukacyjnych opartych na założeniach edukacji inkluzyjnej, w które wpisane są idee włączania i różnorodności. Zgodnie z tymi ideami w każdej jednostce, bez względu na stopień sprawności fizycznej, status ekonomiczny, przynależność kulturową itd. tkwi ważny, z perspektywy edukacji i rozwoju społecznego, potencjał.

Celem niniejszego artykułu jest prezentacja projektu „Przez trudy do gwiazd. Zajęcia wyrównawcze i pozalekcyjne dla uczniów Szkoły Podstawowej nr 26 w Białymstoku"4, w kontekście założeń edukacji inkluzyjnej. Projekt został zrealizowany w roku szkolnym 2012/2013. Jego głównym celem było wyrównywanie szans związanych $\mathrm{z}$ dostępem do edukacji, poprzez zwiększenie możliwości partycypacji w pozalekcyjnych zajęciach edukacyjnych (ze szczególnym uwzględnieniem tych, które rozwijają kompetencje kluczowe).

\section{Różnorodność i inkluzja w edukacji}

W przestrzeni współczesnej edukacji coraz bardziej widoczne są nierówności społeczne, ekonomiczne, odmienność na płaszczyźnie kulturowej, językowej itd. Wzrasta liczba uczniów dobrze usytuowanych, których rodzice, już od najmłodszych lat ich życia, inwestują w edukację na rzecz pomyślnej przyszłości swoich dzieci oraz zaniedbanych wychowawczo. Rośnie odsetek osób postrzeganych jako Obcy, z niepełnosprawnością, żyjących na pograniczu ubóstwa, w środowiskach patologicznych oraz doznających przemocy. W placówkach edukacyjnych pojawia się coraz więcej wychowanków pochodzących z zupełnie odmiennego kontekstu kulturowego, posługujących się diametralnie odmiennym od większościowego kodem kulturowym. Niejednokrotnie wiąże się to $\mathrm{z}$ językowym odizolowaniem, co można zaobserwować wśród wielu osób pochodzących z rodzin imigrantów i uchodźców, które nie komunikują się bądź w słabym stopniu komunikują się w języku polskim. Obecnie z problemem nierówności społecznych i wykluczenia (ekskluzji społecznej)5 borykają się społeczeństwa na całym świecie. Choć w wielu

Z. Bauman, Socjologia, przekł. J. Łoziński, Zysk i S-ka, Poznań 1996, s. 49.

4 Omawiane działanie było współfinansowane przez Unię Europejską w ramach Europejskiego Funduszu Społecznego.

5 Według treści zawartych w Rapport conjoint de la Commission et du Conseil sur l'inclusion Sociale Commission Européenne (2004), wykluczenie społeczne jest to proces, w wyniku którego pewne osoby są wypychane na peryferie społeczeństwa. Utrudnia to im pełne uczestnictwo w życiu społecznym z powodu ubóstwa, braku podstawowych kompetencji i możliwości zdobywania kwalifikacji w ciągu życia lub z powodu dyskryminacji, cyt. 
krajach demokratycznych, na szczeblu narodowym i lokalnym, podejmuje się szereg inicjatyw, aby zmniejszyć przejawy nierówności - wciąż istnieją znaczne różnice dotyczące sytuacji poszczególnych grup społecznych. Przyczyny wykluczenia, nieuczestnictwa, mogą być niezawinione przez jednostkę i niedobrowolne, tzn. leżące poza jej kontrolą. Zdarza się również, że są zawinione i dobrowolne (np. celowe izolowanie się od grupy rówieśniczej). Analizując sytuację edukacyjną, wyłączenie z uczestnictwa cechuje się zazwyczaj niedobrowolnością ${ }^{6}$. Niedobrowolne wykluczenie wynikające $\mathrm{z}$ obiektywnej niezdolności (ubóstwa, niepełnosprawności, choroby itp.) lub braku możliwości (przynależność do mniejszościowej grupy narodowej, etnicznej, płeć, wiek itp.), ma charakter problemu społecznego i tym samym edukacyjnego. Należy zatem podejmować próby jego rozwiązywania dla pomyślności funkcjonowania jednostek w systemie edukacji i społeczeństwie ${ }^{7}$.

Aktywna partycypacja w różnorodnej, dynamicznie zmieniającej się rzeczywistości społeczno-kulturowej wymaga nie tylko nabywania wiedzy, ale również szeregu kompetencji zdobywanych podczas twórczej, kooperatywnej pracy w zróżnicowanym zespole. W roku 2006 przedstawiciele Rady Europy i Parlamentu Europejskiego ${ }^{8}$ dostrzegli, iż w związku z postępującą globalizacją, placówki zajmujące się kształceniem i szkoleniem stają przed nowym wyzwaniem stworzenia przestrzeni do tego, aby uczenie się przez całe życie było dostępne dla wszystkich. Wyzwanie to w szczególności dotyczyło sprostania potrzebom osób uczących się poprzez zapewnienie równości i dostępu do edukacji dla tych wszystkich grup, które ze względu na trudności edukacyjne, spowodowane okolicznościami osobistymi, społecznymi, kulturowymi lub ekonomicznymi, wymagają szczególnego wsparcia w realizacji swojego potencjału edukacyjnego'. Zdefiniowano wówczas osiem kompetencji klu-

za: J. Grotowska-Leder, Ekskluzja społeczna - aspekty teoretyczne i metodologiczne, [w:] Ekskluzja i inkluzja społeczna. Diagnoza - Uwarunkowania - Kierunki działań, J. Grotowska-Leder, K. Faliszek (red.), Akapit, Poznań 2004, s. 19; zob. także: T. Pilch, Źródła i mechanizmy wykluczenia społecznego, [w:] Pedagogika międzykulturowa wobec wykluczenia społecznego i edukacyjnego, T. Lewowicki, A. Szczurek-Boruta, J. Suchodolska (red.), Wydawnictwo Adam Marszałek, Cieszyn - Warszawa - Toruń 2011, s. 88.

6 Por. E. Kantowicz, Społeczne włączanie i integracja - wyzwaniem dla pedagogów i pracowników socjalnych, [w:] Wykluczenie i marginalizacja społeczna. Wokót problemów diagnostycznych i reintegracji psychospołecznej, K. Białobrzeska, S. Kawula (red.), Wydawnictwo Akapit, Toruń 2006, s. 13.

7 Por. ibidem, s. 13.

8 Zalecenia Parlamentu Europejskiego i Rady Europy z dnia 18 grudnia 2006 r. w sprawie kompetencji kluczowych w procesie uczenia się przez całe życie. Dziennik Urzędowy Unii Europejskiej L394, http://eur-lex.europa.eu/LexUriServ/site/pl/oj/2006/1_394/1_3942 oo6123oploo100018.pdf.

9 Ibidem. 
czowych, których kształtowanie stanowi istotny element edukacji inkluzyjnej. Należą do nich: porozumiewanie się w języku ojczystym, porozumiewanie się w językach obcych, kompetencje matematyczne i podstawowe kompetencje naukowo-techniczne, kompetencje informatyczne, umiejętność uczenia się, kompetencje społeczno-obywatelskie, inicjatywność i przedsiębiorczość, świadomość i ekspresja kulturalna.

\section{Założenia edukacji inkluzyjnej}

Zastanawiając się nad wizją edukacji przyszłości, szukamy dziś odpowiedzi na szereg pytań typu: jak kształcić i wychowywać dzieci i młodzież do świadomego uczestnictwa w zróżnicowanym otoczeniu, jak stworzyć możliwość równego dostępu do edukacji dla wszystkich bez względu na sprawność, przystosowanie społeczne, kolor skóry itp. Za nowy paradygmat w pedagogice uznano edukację inkluzyjną (włączającą) ${ }^{10}$, wspierającą proces inkluzji społecznej ${ }^{11}$. Łączy się to z potrzebą wychodzenia naprzeciw problemom nierówności i wykluczenia społecznego, w przeciwdziałaniu którym ważną rolę pełnią edukacja i wychowanie.

Początkowo pojęcie inkluzji w edukacji było utożsamiane $\mathrm{z}$ włączaniem uczniów z niepełnosprawnością $\mathrm{w}$ nurt szkolnictwa ogólnodostępnego ${ }^{12}$. Z czasem zaczęto poszerzać jej definicję, która w ostatecznym brzmieniu została zaproponowana przez UNESCO:

edukacja włączająca jest nieustannie trwającym procesem ukierunkowanym na oferowanie wysokiej jakości edukacji dla wszystkich oraz poszanowania różnorodności, różnych potrzeb i zdolności, właściwości i oczekiwań uczniów i społeczności, eliminującym wszelkie formy dyskryminacji ${ }^{13}$.

Edukacja inkluzyjna powinna być postrzegana jako pomoc w rozwoju człowieka, niezależnie od przeszkód natury fizycznej, społecznej, emocjonal-

10 T. Zacharuk, Edukacja włączająca szansą dla wszystkich uczniów, „Mazowiecki Kwartalnik Edukacyjny" 2011, nr 1 (20), s. 2.

${ }^{11}$ Zob. inkluzja społeczna - włączenie do społeczeństwa - zakłada zmniejszanie nierówności pomiędzy grupami lub wspólnotami najmniej uprzywilejowanymi a pozostałą częścią społeczeństwa poprzez likwidację nierówności oraz udzielanie wsparcia tym, którzy go potrzebują. Inkluzja w edukacji jest rodzajem dążeń, kierunkiem zmian, opisywanych m.in. w takich dokumentach, jak Deklaracja UNESCO z Salamanki z 1994 r., a następnie podkreślanych w Konwencji praw osób niepełnosprawnych ONZ z 2006 r.

12 B. Papuda-Dolińska, Realizacja koncepcji inkluzji edukacyjnej w szkołach planu jenajskiego - doświadczenia holenderskie, www.konferencja.21.edu.pl [20.05.2013].

13 Zob. D. Mitchell, Education that Fits: Review of International Trends in the Education of Students with Special Educational Needs, „Education Counts” 2012, cyt. za: B. Papuda-Dolińska, op. cit. 
nej itp. Tamara Zacharuk wymienia następujące cechy charakterystyczne dla edukacji włączającej $j^{14}$ :

- uznaje ona, że wszystkie dzieci mogą się uczyć,

- uznaje i szanuje zróżnicowanie pod względem wieku, płci, pochodzenia etnicznego, języka, niepełnosprawności itd.,

- pozwala systemowi oraz strukturom edukacji, a także metodyce poznać potrzeby wychowanków i uczy, jak im sprostać,

- stanowi część szerszej strategii promowania społeczeństwa inkluzyjnego,

- jest dynamicznym procesem, który ciągle się rozwija.

Wymaga ona szerokiej wizji „Edukacji dla Wszystkich”, ${ }^{15}$, realizowanej z troski o potrzeby wychowanków, nie pomijając tych, którzy narażeni są na wykluczenie i marginalizację ${ }^{16}$.

Przebieg procesu inkluzji edukacyjnej zależy od wiedzy i umiejętności osób odpowiedzialnych za proces edukacyjny oraz struktury zarządzania placówką. Zależny jest on także od warunków zewnętrznych i wewnętrznych: bazy placówki i jej zasobów, społeczności wychowanków, ich rodziców, środowiska lokalnego i możliwości współpracy z nim. To edukacja skupiona bardziej na uczestniku procesu edukacyjnego niż na programie pracy czy nauczania, dająca gwarancję równouprawnienia wszystkim wychowankom, także tym ze specjalnymi potrzebami edukacyjnymi i wykazującymi trudność w uczeniu się.

Inkluzja (włączanie) łączy się z odkrywaniem potencjału oraz piękna różności, a nie koncentrowaniem się na brakach. Pozwala na rozbudzenie w przestrzeni codziennego życia ducha współpracy i wzajemnego szacunku, inspirującego do wzbogacania naszego doświadczenia nowymi punktami widzenia.

\section{Projekt edukacyjny „Przez trudy do gwiazd”}

Projekt powstał z myślą o dzieciach w wieku 10-12 lat, różniących się od siebie w wielu zakresach (interpersonalnym, społecznym, kulturowym) i tym samym pochodzących $\mathrm{z}$ różnych środowisk wychowawczych (w tym dysfunkcyjnych). Wybór grupy docelowej poprzedzony był dogłębną analizą treści dokumentów szkolnych (np. wyniki sprawdzianów po klasie VI, dokumentacja wychowawcy klasy i pedagoga szkolnego) i obserwacjami nauczycieli, któ-

${ }_{14}$ T. Zacharuk, op. cit., s. 4, zob. także: D. Wiszejko-Wierzbicka, Specjalne potrzeby ucznia czy szkoły? Przewodnik po edukacji właczajacej pomoca w rozwijaniu kształcenia i uczestnictwa $w \dot{z} y$ ciu szkoły, www.webcache.googleusrcontent.com/search=cache:APGVxwAC $\mathrm{TaOJ}$ [15.05.2013].

15 Guidelines for inclusion: ensuring Access to education for All, France 2004, UNESCO, cyt. za: T. Zacharuk, op. cit., s. 4.

16 Ibidem. 
rzy wśród uczniów szkoły dostrzegali spadek aktywności w kierunku rozwijania swojego potencjału osobowego $\mathrm{z}$ uwagi na utrudniony dostęp do dodatkowych form kształcenia, spowodowany najczęściej barierą finansową. W wielu przypadkach skutkowało to pogłębiającymi się zaległościami w nauce, wzrostem ryzyka niepowodzeń szkolnych, w konsekwencji - wykluczeniem z życia społecznego. Uczniom brakowało wsparcia rodziców, którzy nie przykładali wagi do edukacji swoich dzieci i nie mieli świadomości konieczności rozwijania przez nie kompetencji uznawanych za kluczowe. Liczną grupę beneficjentów projektu stanowili uczniowie uchodźcy, najczęściej pochodzący z Czeczenii i innych krajów kaukaskich. Nieznajomość języka polskiego, bariery kulturowe, przekładały się na niepowodzenia szkolne tychże uczniów oraz częstsze ich wypadanie z polskiego systemu edukacji. W ramach projektu podjęto realizację następujących zadań:

1. Zajęcia dydaktyczno-wyrównawcze z języka polskiego z wykorzystaniem tablicy interaktywnej.

2. Doskonalenie kompetencji językowych - nauka języka angielskiego z wykorzystaniem tablicy interaktywnej.

3. Wirtualne podróże, czyli uczymy się wykorzystywać technologie IT.

4. Przekraczamy granice - dodatkowe lekcje doskonalące porozumiewanie się w języku polskim dla uczniów-uchodźców.

5. Z mapą, cyrklem i aparatem przez świat - zajęcia doskonalące kompetencje matematyczne i naukowo-techniczne.

6. Sprawdzianu się nie boimy, bo systematycznie ćwiczymy - cykl zajęć matematyczno-przyrodniczych.

7. Zajęcia rozwijające aktywność twórczą, świadomość kulturalną i zdolności sportowe (koszykówka, szachy, tenis stołowy).

8. Warsztaty grupowe dla uczniów klas VI z doradcą zawodowym w celu aktywizowania uczniów do podejmowania samodzielnych decyzji edukacyjno-zawodowych.

W toku działania dostrzeżono, że do podwyższenia rezultatów uczenia się oraz efektywności pracy uczniów przyczyniła się niewątpliwie stosowana strategia pracy - kooperatywne uczenie się, które wymagało małej liczebności grup oraz aktywnych metod. Prowadzący, na podstawie autorskich programów i scenariuszy zajęć, poprzez wyzwalanie uzdolnień i możliwości tkwiących w uczestnikach projektu, także tych o specjalnych potrzebach edukacyjnych, stwarzali przestrzeń do osiągania i doświadczania sukcesów ${ }^{17}$.

17 Rozporządzenie MEN z dnia 27 sierpnia 2012 r. w sprawie warunków organizowania kształcenia, wychowania i opieki dla dzieci i młodzieży niepełnosprawnych oraz niedo- 

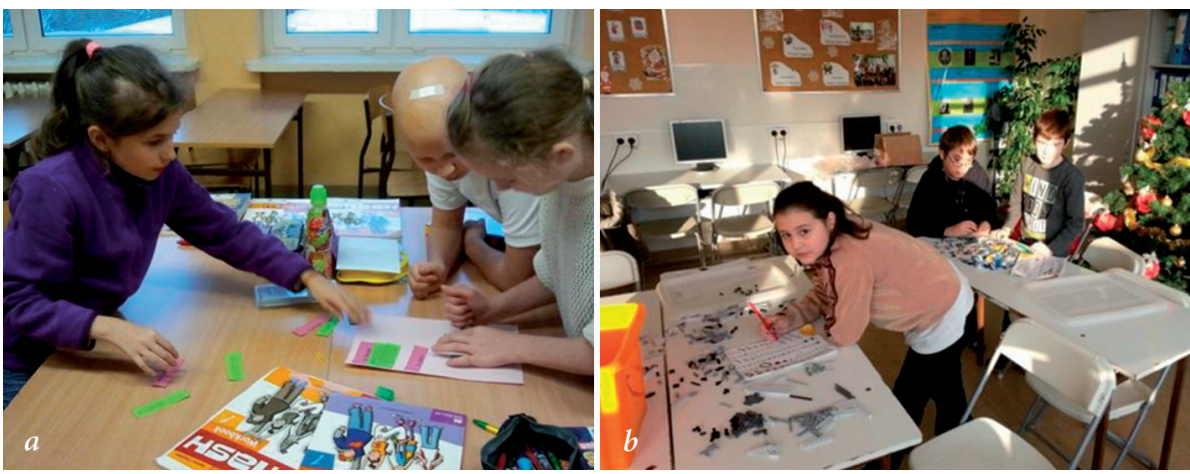

Fotografia 1: a) aktywna nauka $w$ grupach, b) praca nad projektem

Źródło: $\mathrm{z}$ archiwum projektu.

Ponieważ dobra szkoła wyrównuje szanse edukacyjne uczniów dzięki temu, że umacnia ich aktywność i samodzielność, stąd praca na zajęciach oparta była również na metodzie projektu ${ }^{18}$. Stosowana strategia oraz metody pracy umożliwiały uczniom wspólną pracę nad różnymi zadaniami, wspieranie się i rozwijanie kompetencji kluczowych. Wzbudzało to $\mathrm{w}$ dzieciach potrzebę okazywania szacunku innym oraz potrzebę tolerancji dla odmiennych poglądów czy postaw. Potwierdzają to wypowiedzi uczestników projektu:

Każda lekcja był inna. Uczyliśmy się przez zabawę. To nie były takie nudne lekcje [...]. Były różne osoby: piąto- i szóstoklasiści. Mimo różnicy wieku, dobrze się porozumiewaliśmy. Na przykład niektóre osoby gorzej czytały, a niektóre gorzej pisały. Niektórym osobom więcej czasu zajmowało, żeby rozwiązać niektóre zagadki. Czasami, jak niektóre osoby nie wiedziały czegoś, to staraliśmy się im pomóc (Agata, 12 lat, wypowiedź na temat zajęć z języka polskiego rozwijających kompetencje komunikacyjne).

Zajęcia na pewno były pomocne. Nauczyłam się czegoś więcej. Zrozumiałam tematy, których nie mogłam wcześniej zrozumieć. Pomocne to było podczas nauki w szkole. Podobało mi się. Chętnie pracowaliśmy w grupach. Korzystaliśmy z tablicy interaktywnej, robiliśmy różne zadania (Julia, 12 lat, wypowiedź na temat zajęć z języka angielskiego rozwijających kompetencje językowe).

Zajęcia nauczyły nas współpracy pomiędzy starszymi i młodszymi. Były klasy: czwarta, piąta i szósta. Pan nam pokazał, że można współpracować z młodszymi. Pracowaliśmy razem - jako jedna całość przy pomocy naszego eksperta, czyli

stosowanych społecznie w przedszkolach, szkołach i oddziałach ogólnodostępnych lub integracyjnych.

18 G. Mańko, Wyrównywanie szans edukacyjnych - poradnik praktyczny [online], www. szkola.szans.pl/pl/index.phpoption=com_docman\&task=doc_view\&gid+159 [4.10.2008]. 
naszego pana nauczyciela (Maciej, 12 lat, wypowiedź na temat zajęć rozwijających kompetencje informatyczne).

Podczas każdych zajęć w centrum procesu edukacyjnego znalazł się uczeń, który z jednej strony konstruował swoją wiedzę, poszukując i badając, był uczestnikiem procesu uczenia się przez doświadczenie ${ }^{19}$, a z drugiej strony miał możliwość samopoznania, w tym swoich możliwości w procesie edukacji. Prowadzący zajęcia starali się pobudzać aktywność uczestników, zachęcać do podejmowania osobistych przemyśleń i poszukiwań. Stwarzali sytuacje problemowe, prowokowali do zadawania pytań i uczyli argumentowania wniosków, co wspierało myślenie krytyczne oraz umożliwiało dostrzeganie potencjału twórczego $\mathrm{w}$ różnorodności.

Robiliśmy dużo doświadczeń. Były one w ciekawy sposób prowadzone. Pani nam pokazywała i każdy z nas mógł zrobić doświadczenia fizyczne, chemiczne, rozwiązywaliśmy różne zadania matematyczne. Na pewno łatwiej jest, jak się coś zobaczy, jakąś reakcję niż jak się czyta z książki. Jak samemu można coś zrobić, zobaczyć, bo z książki jest tak trudno sobie wyobrazić. Każdy mógł spróbować. Nikt się nie stresował, że coś nie wyjdzie. Pani pomagała, wszyscy pomagali sobie. Poznałam też dużo ciekawych osób. Spontanicznie wychodziło w grupach - wspólnie (Aleksandra, 12 lat, wypowiedź na temat zajęć matematyczno-przyrodniczych).

Podejmowano także działania na rzecz rozbudzania kompetencji osobistych i społecznych ${ }^{20}$. Uczniowie dokonywali samooceny - poznawali swoje mocne i słabe strony, uczyli się panowania nad emocjami, wyrażania satysfakcji z wykonanej pracy. Rozwój kompetencji społecznych widoczny był w stopniu radzenia sobie uczestników w relacjach z innymi ludźmi. Dostrzegały to dzieci, kiedy podczas wywiadów mówiły:

Na zajęciach z doradcą uczyliśmy się pracy w grupie. Na przykład pani podzieliła nas, żeby nie było równo. Okazało się, że w tej grupie, gdzie były dwie osoby, udało zrobić się więcej niż w tej, gdzie były cztery osoby. To nauczyło nas tego, że trzeba współpracować ze sobą, a nie kłócić się (Dominika, 12 lat, wypowiedź na temat zajęć z doradztwa zawodowego).

Tak sobie pomyślałam, że dobrze jest się uczyć, że mamy prawo do nauki, że wiele rzeczy możemy dzięki temu zrobić. Zastanawiały mnie niektóre rzeczy, które się działy. I miałam wiele takich przemyśleń. Nawiązałam lepszy kontakt z niektórymi ludźmi. Zrozumiałam, że nie zawsze możemy być najlepsi. Że jak się współ-

19 B. Chojnacka-Synaszko, Wykluczenie czy wspieranie uczniów? - podejście nauczycieli i przyszłych pedagogów do realizacji zadań współczesnej szkoły, [w:] Pedagogika międzykulturowa wobec wykluczenia społecznego i edukacyjnego, T. Lewowicki, A. Szczurek-Boruta, J. Suchodolska (red.), Wydawnictwo Adam Marszałek, Toruń 2011, s. 271. 

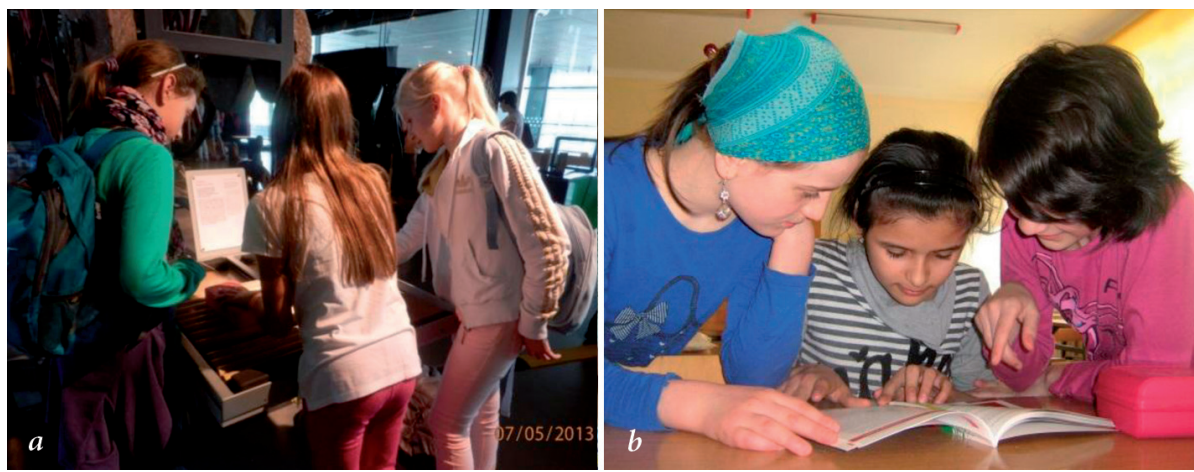

Fotografia 2: a) nabywanie wiedzy przyrodniczej w praktyce, b) rozwiązywanie łamigłówki językowej

Źródło: $\mathrm{z}$ archiwum projektu.

pracuje, to jest fajnie, jest dużo zabawy. Tak można lepiej się nauczyć czegoś, zrozumieć (Agata, 12 lat, wypowiedź na temat zajęć z doradztwa zawodowego).

Analiza wskaźników końcowych projektu wykazała wzrost wiedzy i umiejętności uczniów w zakresie kompetencji kluczowych. Wartością dodaną był mniejszy odsetek uczniów kierowanych do Poradni Psychologiczno-Pedagogicznej. Zwiększyła się liczba uczniów rozwijających swoje talenty w różnych placówkach oświatowych. Uczniowie zaczęli odnosić sukcesy w konkursach na szczeblu szkolnym i pozaszkolnym. Poprzez wzrost motywacji do nauki i dalszego kształcenia zmniejszyło się ryzyko wykluczenia edukacyjnego i społecznego. Dzięki zastosowaniu aktywnych metod pracy uczniowie nabywali umiejętności pracy w zespole. Zmniejszenie bariery językowej wśród uczniów-uchodźców polepszyło funkcjonowanie uchodźców w środowisku szkolnym.

\section{Zakończenie}

Poznanie i zaakceptowanie różnorodności wydaje się najlepszą drogą kreowania włączającego społeczeństwa. Dlatego realizacja idei edukacji inkluzyjnej doskonale wpisuje się w kierunek współczesnej polityki oświatowej na rzecz przeciwdziałania wykluczeniu społecznemu, przemocy, nietolerancji i marginalizacji. Edukacja włączająca jest przykładem alternatywy dla standardowych systemów edukacyjnych, która upowszechnia prawo jednostki do indywidualności oraz wspierającej nieskrępowany rozwój każdego człowieka bez względu na istniejące różnice. Projekt edukacyjny „Przez trudy do gwiazd” stanowi przykład inicjatywy na rzecz różnorodności i włączania - 
działania, dzięki któremu możliwe stało się wyrównywanie szans edukacyjnych, rozwijanie kompetencji kluczowych oraz tworzenie możliwości pełnego uczestnictwa w procesie edukacyjnym osobom różniącym się od siebie w różnych zakresach.

\section{BIBLIOGRAFIA}

Bauman Z., Socjologia, przekł. J. Łoziński, Zysk i S-ka, Poznań 1996.

Deklaracja UNESCO z Salamanki z 1994 r.

Chojnacka-Synaszko B., Wykluczenie czy wspieranie uczniów? - podejście nauczycieli i przyszłych pedagogów do realizacji zadań współczesnej szkoły, [w:] Pedagogika międzykulturowa wobec wykluczenia społecznego i edukacyjnego, T. Lewowicki, A. Szczurek-Boruta, J. Suchodolska (red.), Wydawnictwo Adam Marszałek, Toruń 2011.

Grotowska-Leder J., Ekskluzja społeczna - aspekty teoretyczne i metodologiczne, [w:] Ekskluzja i inkluzja społeczna. Diagnoza - Uwarunkowania - Kierunki działań, J. Grotowska-Leder, K. Faliszek (red.), Akapit, Poznań 2004.

Guidelines for inclusion: ensuring Access to education for All, UNESCO, France 2004.

Grzybowski P. P., Edukacja międzykulturowa - przewodnik. Pojęcia - literatura - adresy, Oficyna Wydawnicza Impuls, Kraków 2008.

Kantowicz E., Społeczne włączanie i integracja - wyzwaniem dla pedagogów i pracowników socjalnych, [w:] Wykluczenie i marginalizacja społeczna. Wokół problemów diagnostycznych i reintegracji psychospołecznej, K. Białobrzeska, S. Kawula (red.), Akapit, Toruń 2006.

Konwencja praw osób niepełnosprawnych ONZ z 2006 r.

Mańko G., Wyrównywanie szans edukacyjnych - poradnik praktyczny [online], www. szkola. szans.pl/pl/index.phpoption=com_docman\&task=doc_view\&gid+15 9 .

Mitchell D., Education that Fits: Rewiew of International Trends in the Education of Students with Special Educational Needs, „Education Counts” 2012.

Nikitorowicz J., Kreowanie tożsamości dziecka. Wyzwania edukacji międzykulturowej, Gdańskie Wydawnictwo Psychologiczne, Gdańsk 2005.

Papuda-Dolińska B., Realizacja koncepcji inkluzji edukacyjnej w szkołach planu jenajskiego - doświadczenia holenderskie, www.konferencja.21.edu.pl.

Pilch T., Źródła i mechanizmy wykluczenia społecznego, [w:] Pedagogika międzykulturowa wobec wykluczenia społecznego i edukacyjnego, T. Lewowicki, A. Szczurek-Boruta, J. Suchodolska (red.), Wydawnictwo Adam Marszałek, Cieszyn - Warszawa - Toruń 2011.

Rozporządzenie MEN z dnia 27 sierpnia 2012 r. w sprawie warunków organizowania kształcenia, wychowania i opieki dla dzieci i młodzieży niepełnosprawnych oraz niedostosowanych społecznie w przedszkolach, szkołach i oddziałach ogólnodostępnych lub integracyjnych.

Zalecenia Parlamentu Europejskiego i Rady Europy z dnia 18 grudnia 2006 r. w sprawie kompetencji kluczowych w procesie uczenia się przez całe życie. Dziennik Urzędowy Unii Europejskiej L394, http://eur-lex.europa.eu/LexUriServ/site/pl/oj/2006/1_394/1_39420061230pl oo100018.pdf.

Zacharuk T., Edukacja włączająca szansą dla wszystkich uczniów, „Mazowiecki Kwartalnik Edukacyjny" 2011, 1 (20).

Wiszejko-Wierzbicka D., Specjalne potrzeby ucznia czy szkoły? Przewodnik po edukacji właczającej pomoca $w$ rozwijaniu kształcenia i uczestnictwa w życiu szkoły, www.webcache. googleusrcontent. com/search=cache:APGVxwACTaOJ. 
SUMMARY

\section{Through the difficulties to the stars. \\ Inclusion and diversity in education}

The main purpose of this paper is to present educational project "Through the difficulties to the stars", in the context of inclusive education assumptions. The authors of the article begin with showing the issue of diversity and inclusion in education and inclusive education assumptions. Afterwards they present the idea of the project "Through the difficulties to the stars". The last part of the paper is enriched by the project participants' statements about their experiences connected with participation in the initiative.

KEY WORDS: diversity, inclusive education, key competences, cooperative learning. 